\title{
OCENA JAKOŚCI ŻYCIA PACJENTÓW ZE STWARDNIENIEM ROZSIANYM
}

\section{EVALUATION OF THE QUALITY OF LIFE OF PATIENTS WITH MULTIPLE SCLEROSIS}

\author{
Hanna Skórzyńska', Marlena Krawczyk-Suszek², Anna Pacian¹ \\ ${ }^{1}$ Wydział Nauk o Człowieku, Wyższa Szkoła Ekonomii I Innowacji, Lublin \\ ${ }^{2}$ Katedra Fizjoterapii, Wydział Medyczny, Wyższa Szkoła Informatyki i Zarządzania w Rzeszowie \\ DOI: https://doi.org/10.20883/ppnoz.2019.16
}

\section{STRESZCZENIE}

Wstęp. Stwardnienie rozsiane jest chorobą przyczyniającą się do powstania i pogłębiania się niepełnosprawności. Problemy u pacjentów zdiagnozowanych na SM dotyczą nie tylko sfery fizycznej, w której obserwuje się zaburzenie czynności motorycznych i funkcjonalnych narządów, ale także złożone problemy natury psychicznej w procesie zmagania się z postępującą i wyniszczającą chorobą.

Cel. Celem pracy była ocena jakości życia pacjentów ze stwardnieniem rozsianym oraz określenie wpływu choroby i innych czynników na satysfakcję z życia chorych.

Materiał i metoda. Badanie zostało przeprowadzone w grupie 100 pacjentów ze zdiagnozowanym stwardnieniem rozsianym (SM). Do oceny jakości życia został wykorzystany standaryzowany kwestionariusz MSIS - 29. Wyniki zostały poddane analizie statystycznej przy wykorzystaniu pakietu STATISTICA. Wyniki. Średnia wartość punktów uzyskiwanych w analizie sfery psychologicznej wynosiła X $=40,33$. Sfera ta została oceniona nieco gorzej w porównaniu ze sferą fizyczną, gdzie średnia wynosiła $X=40,61$. Wiek $(p=0,000)$ i czas trwania choroby $(p=0,000)$ istotnie wpływały na ocenę dwóch sfer życia u pacjentów. Postać rzutowo-przewlekła i wtórnie przewlekła istotnie obniżają jakość życia u pacjentów.

Wnioski. Jakość życia w grupie pacjentów ze zdiagnozowanym SM jest niezadowalająca. Kobiety częściej wskazują na problemy natury psychologicznej będące następstwem choroby, natomiast mężczyźni nie potrafią pogodzić się z problemami związanymi z funkcjonalnością organizmu. Osoby czynne zawodowo lepiej oceniają jakość życia w porównaniu z osobami bezrobotnymi, emerytami i rencistami.

Słowa kluczowe: jakość życia, stwardnienie rozsiane, MSIS - 29.

ABSTRACT

Introduction. Multiple sclerosis is a disease that contributes to the emergence and deepening of disability. Problems in patients diagnosed with MS relate not only to the physical sphere in which the dysfunction of motor function and functional organs is observed, but also complex psychological problems in the process of coping with progressive and debilitating disease.

Aim. The aim of the study was to assess the quality of life of patients with multiple sclerosis and to determine the impact of disease and other factors on the patients' life satisfaction.

Material and method. The study was conducted in a group of 100 patients with diagnosed multiple sclerosis (MS). A standardized MSIS questionnaire was used to assess the quality of life MSIS - 29. The results were analyzed statistically using the STATISTICA package.

Results. The average value of points obtained in the analysis of the psychological sphere was $X=40.33$. This sphere was rated a bit worse compared to the physical sphere, where the average was $X=40.61$. The age $(p=0.000)$ and the duration of the disease $(p=0.000)$ significantly influenced the assessment of the two spheres of life in patients. The relapsing-chronic and secondary-chronic forms significantly reduce the quality of life in patients.

Conclusions. The quality of life in the group of patients with diagnosed SM is unsatisfactory. Women more often indicate psychological problems that are a consequence of illness, while men can not come to terms with problems related to the functionality of the body. Professionally active people assess the quality of life better than unemployed persons and pensioners.

Keywords: quality of life, multiple sclerosis, MSIS - 29.

\section{Wstęp}

Stwardnienie rozsiane (Sclerosis Multiplex - SM) jest autimmunologiczną chorobą zapalną ośrodkowego układu nerwowego o charakterze postępującym. Najczęściej dotyka osoby młode między 20. a 40. rokiem życia. Znane są także przypadki zdiagnozowania choroby $w$ grupie dzieci i osób starszych. Dwukrotnie częściej SM dotyka kobiet niż mężczyzn. Występuje głównie wśród ludzi zamieszkujących klimat umiarkowany i chłodny, jak również w pań- stwach, gdzie cywilizacja jest wysoce rozwinięta. Częściej odnotowuje się przypadki zachorowań wśród rasy białej, amerykanie afrykańskiego pochodzenia chorują rzadziej. Najwięcej zachorowań odnotowuje się w krajach europejskich (Polska, Rosja), w północnej części Stanów Zjednoczonych, w południowej części Kanady, Nowej Zelandii oraz w południowo-wschodniej Australii $[1,2,3]$.

W następstwie przewlekłej choroby, okresów rzutu i remisji, stopień niepełnosprawności osób cierpiących na 
SM stale zwiększa się, obniżając jakość życia. W ostatnich latach wzrosło zainteresowanie jakością życia (quality of life - QL) pacjentów w procesie chorobowym. Zaczęto wiązać ją z fizycznymi, psychicznymi i społecznymi dziedzinami życia. Za pomocą kwestionariuszy do pomiaru jakości życia zwiększa się możliwość określenia satysfakcji pacjenta z wyników leczenia, oceniając funkcjonowanie w wymiarze fizycznym i społecznym, zdolność wypełniania ról społecznych, rodzinnych i zawodowych podczas trwania procesu chorobowego $[4,5,6]$.

\section{Cel}

Głównym celem badań była ocena jakości życia pacjentów ze zdiagnozowanym stwardnieniem rozsianym oraz wskazanie czynników istotnie ją determinujących.

\section{Materiał i metoda}

Badanie zostało przeprowadzone w grupie 100 losowo wybranych osób, u których zdiagnozowano stwardnienie rozsiane. Byli to pacjenci diagnozowani w Pracowni Rezonansu Magnetycznego SPSK nr 1 w Lublinie oraz osoby, który dobrowolnie wzięły udział w badaniu na forum internetowym.

Zastosowano metodę sondażu diagnostycznego z wykorzystaniem kwestionariusza standaryzowanego MSIS - 29. Pytania zawarte w kwestionariuszu odnoszą się do stanu pacjenta w ostatnich 2 tygodniach. Dotyczą ograniczenia zdolności fizycznych, stanów uciążliwych pacjenta, sytuacji, które denerwowały pacjenta oraz stanów wskazujących na obniżenie nastroju. Pacjent może uzyskać od 0 do 100 punktów, jednocześnie im mniej punktów, tym jakość życia pacjenta jest lepsza [7].

\section{Wyniki}

Badanie przeprowadzono w grupie 100 osób, u których zdiagnozowano stwardnienie rozsiane. Wśród badanych $69 \%$ stanowiły kobiety, pozostały odsetek to mężczyźni (31\%). Pacjenci poddani badaniu ankietowemu byli w wieku od 19 do 58 lat. Średnia wieku w badanej grupie wynosiła $35,98 \pm 10,28$ lat. W badanej grupie dominował odsetek osób z wykształceniem wyższym (58\%) i średnim (34\%). Najmniej liczną grupę stanowiły osoby z tytułem zawodowym (6\%) oraz osoby deklarujące ukończenie szkoły podstawowej (2\%). Większość ankietowanych zamieszkiwało tereny miejskie (71\%), 29\% wskazywało jako miejsce zamieszkania wieś. Analizując stan cywilny pacjentów, stwierdzono, że najliczniejszą grupę stanowiły osoby zamężne (59\%), pozostała część to osoby stanu wolnego (38\%) i osoby samotne po utracie współmałżonka (3\%). Niemal połowa z badanych to osoby aktywne zawodowo
(47\%), 40\% deklarowało posiadanie prawa do pobierania renty bądź emerytury (40\%). Najmniej liczną grupę stanowiły osoby bezrobotne, odsetek ten wynosił 13\%. Czas trwania zdiagnozowanej choroby w grupie badanych pacjentów wahała się od nowo zdiagnozowanego do trwającego od 25 lat schorzenia. Średni czas trwania choroby wgrupiepacjentówpoddanychbadaniuwyniosła8,18 $\pm 6,06$ lat. W badanej grupie pacjentów najczęściej występującą postacią SM była postać remitująco-rzutowa, co wskazało $38 \%$ badanych. Wtórnie przewlekłą postać deklarowało 11\% pacjentów, u 9\% zdiagnozowano postać pierwotnie przewlekłą, natomiast pozostali chorowali na SM postaci rzutowo-przewlekłej (5\%). Znaczący odsetek pacjentów nie potrafiło udzielić odpowiedzi na pytanie dotyczące postaci zdiagnozowanego SM. Odsetek ten był znaczny i wynosił 37\% ogółu badanych (Wykres 1).

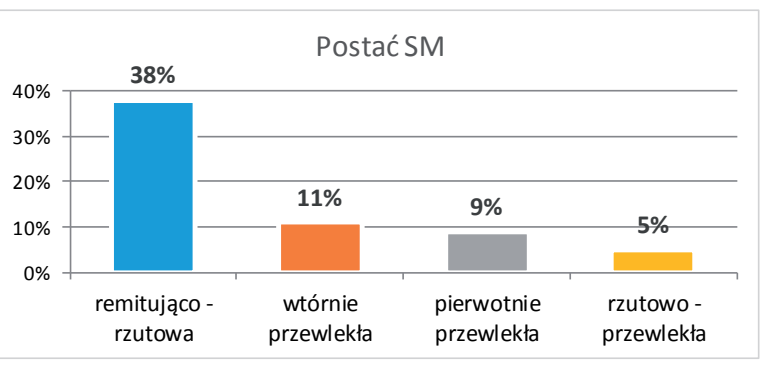

Wykres 1. Postać stwardnienia rozsianego

Średnia wartość punktów uzyskiwanych w sferze fizycznej według kwestionariusza MSIS-29 wśród badanych pacjentów wynosiła $X=40,61 \pm 28,18$. Analizując pierwsze 20 pytań dotyczących stanu fizycznego pacjenta, do grupy osób z brakiem problemów natury fizycznej przyporządkowano 27\%. Wśród osób z kilkoma problemami znalazło się 26\% badanych, natomiast z umiarkowaną ilością problemów 16\%. Część spośród badanych według MSIS-29 posiada sporo problemów natury fizycznej (19\%), a nawet dużo (12\%) (Tabela 1).

Tabela 1. Częstość występowania problemów w sferze fizycznej życia wg kwestionariusza MSIS-29

\begin{tabular}{|l|c|c|}
\multicolumn{1}{|c|}{$\begin{array}{c}\text { Sfera } \\
\text { fizyczna }\end{array}$} & Częstość & Procent \\
brak problemów & 27 & $\%$ \\
kilka problemów & 26 & 27 \\
umiarkowana ilość & 16 & 16 \\
problemów & 19 & 19 \\
sporo problemów & 12 & 12 \\
dużo problemów & 100 & 100 \\
ogółem & &
\end{tabular}


Średnia wartość punktów uzyskiwanych w sferze psychologicznej w kwestionariuszu MSIS-29 przez pacjentów wynosiła $X=40,33 \pm 25,59$. Większość spośród badanych wskazywała pojawienie się kilku problemów natury psychologicznej związanych ze stwierdzoną chorobą (36\%). Spośród badanych $19 \%$ deklarowało, że posiadały sporo problemów, a 14\% umiarkowaną ich ilość. Najwięcej problemów miało 8\% badanych, wskazując na dużą częstość ich występowania w sferze psychologicznej. W grupie osób bez problemów w sferze emocjonalnej znalazło się $23 \%$ badanych pacjentów.

Tabela 2. Częstość występowania problemów w sferze psychologicznej według kwestionariusza MSIS-29

\begin{tabular}{|l|c|c|}
\multicolumn{1}{|c|}{ Sfera } & Częstość & Procent \\
psychologiczna & N & $\%$ \\
brak problemów & 23 & 23 \\
kilka problemów & 36 & 36 \\
\hline umiarkowana ilość problemów & 14 & 14 \\
sporo problemów & 19 & 19 \\
\hline dużo problemów & 8 & 8 \\
\hline ogółem & 100 & 100 \\
\hline
\end{tabular}

Analizując punktową ocenę dwóch sfer życia pacjenta ze stwierdzonym stwardnieniem rozsianym: fizycznej i psychologicznej, wskazano istotną zależność między badanymi cechami a wiekiem badanych $(p=0,000)$. Zaobserwowano pogarszającą się jakość życia w obu badanych sferach wraz z wiekiem. Istotną korelację wskazano, analizując czas trwania choroby. Dłuższy czas trwania choroby znacznie pogarsza jakość funkcjonowania pacjenta w obu sferach badanych w kwestionariuszu MSIS-29 (Tabela 3).

Tabela 3. Jakość życia pacjentów ze stwardnieniem rozsianym z uwzględnieniem czasu trwania choroby i wiekiem respondentów

\begin{tabular}{|c|c|c|c|}
\hline \multicolumn{2}{|c|}{$\begin{array}{l}\text { Sfery } \\
\text { życia }\end{array}$} & Wiek & $\begin{array}{l}\text { Czas } \\
\text { trwania } \\
\text { choroby }\end{array}$ \\
\hline $\begin{array}{l}\text { MSIS - sfera } \\
\text { fizyczna }\end{array}$ & $\begin{array}{l}\text { korelacja } \\
\text { Pearsona } \\
\text { p-wartość }\end{array}$ & $\begin{array}{c}, 496 * * \\
, 000\end{array}$ & $\begin{array}{c}, 614^{* *} \\
, 000\end{array}$ \\
\hline $\begin{array}{l}\text { MSIS } \\
\text { - sfera } \\
\text { psychologiczna }\end{array}$ & $\begin{array}{c}\text { korelacja } \\
\text { Pearsona } \\
\text { p-wartość }\end{array}$ & $\begin{array}{l}.429 * * \\
, 000\end{array}$ & $\begin{array}{l}, 598^{* *} \\
, 000\end{array}$ \\
\hline $\begin{array}{l}\text { Zmienna } \\
\text { w korelacji }\end{array}$ & $\begin{array}{l}\text { korelacja } \\
\text { Pearsona } \\
p \text { - wartość }\end{array}$ & $\begin{array}{l}1 \\
-\end{array}$ & $\begin{array}{l}1 \\
-\end{array}$ \\
\hline
\end{tabular}

**korelacja jest istotna na poziomie 0,01

Jakość życia pacjentów w badanej grupie istotnie zależała od miejsca zamieszkania. W przypadku obu badanych sfer wyniki różniły się istotnie $w$ grupach miesz- kańców miast i wsi $(p<0,05)$. Wyniki z kwestionariusza MSIS-29, które zostały uzyskane przez mieszkańców wsi były istotnie niższe niż w grupie mieszkańców miast. Wartość mediany punktów wskazywanych w sferze fizycznej w grupie pacjentów zamieszkujących tereny wiejskie była istotnie niższa w porównaniu z drugą grupą i wynosiła $M e=25$. Zjawisko to obserwowane jest także $w$ analizie sfery psychologicznej pacjentów, gdzie wartość mediany dla mieszkańców wsi i miasta wynosiła odpowiednio $\mathrm{Me}_{\mathrm{w}}=30,6$ oraz $\mathrm{Me}_{\mathrm{m}}=36$. Oznacza to, że jakość życia pacjentów mieszkających na wsi była przez nich wyżej oceniania w porównaniu z osobami zamieszkującymi tereny miejskie (Tabela 4).

Tabela 4. Jakość życia pacjentów z SM z uwzględnieniem miejsca zamieszkania

\begin{tabular}{|c|c|c|c|c|c|}
\hline \multicolumn{2}{|l|}{ Korelacje } & $N^{*}$ & Me* & $\begin{array}{l}\text { U Manna- } \\
\text {-Whitneya }\end{array}$ & $\begin{array}{c}p- \\
\text { wartość }\end{array}$ \\
\hline \multirow{2}{*}{$\begin{array}{l}\text { MSIS - sfera } \\
\text { fizyczna }\end{array}$} & miasto & 71 & 42,5 & \multirow{2}{*}{662,0} & \multirow{2}{*}{, 005} \\
\hline & wieś & 29 & 25,0 & & \\
\hline \multirow{2}{*}{$\begin{array}{l}\text { MSIS } \\
\text { - sfera } \\
\text { psychologiczna }\end{array}$} & miasto & 71 & 36,1 & \multirow{2}{*}{749,50} & \multirow{2}{*}{,033 } \\
\hline & wieś & 29 & 30,6 & & \\
\hline
\end{tabular}

*N - liczba obserwacji; Me - mediana

Mała liczność niektórych postaci choroby nie pozwoliła na zbadanie formalnej zależności. Całość oceniono poprzez analizę wzrokową wykresu. Najwyższe wyniki, oznaczające gorszą jakość życia ze stwardnieniem rozsianym, uzyskały osoby chorujące na postaci przewlekłe choroby (pierwotnie przewlekła, wtórnie przewlekła, rzutowoprzewlekła). Pacjenci, którzy mają zdiagnozowaną postać remitująco-rzutową jakość życia oceniają zdecydowanie lepiej, co pokazują poniższe wyniki uzyskane z kwestionariusza MSIS-29. Do zobrazowania wyników wykorzystano średnie wartość uzyskiwanych punktów (Wykresy 2 i 3).

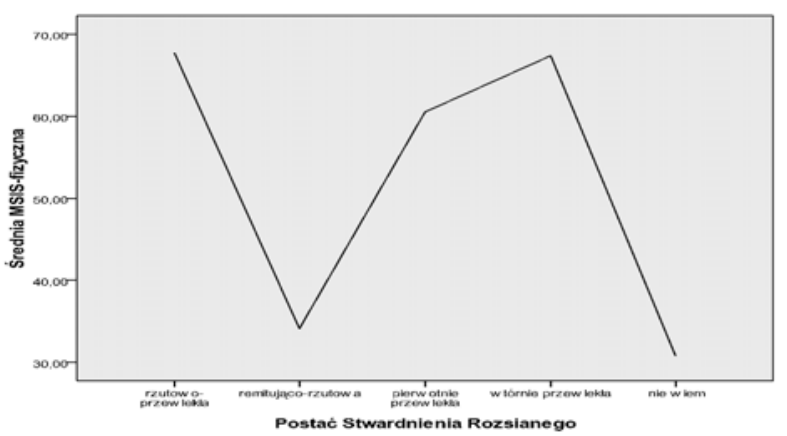

Wykres 2. Jakość życia badanych w sferze fizycznej z uwzględnieniem postaci choroby wg MSIS-29 


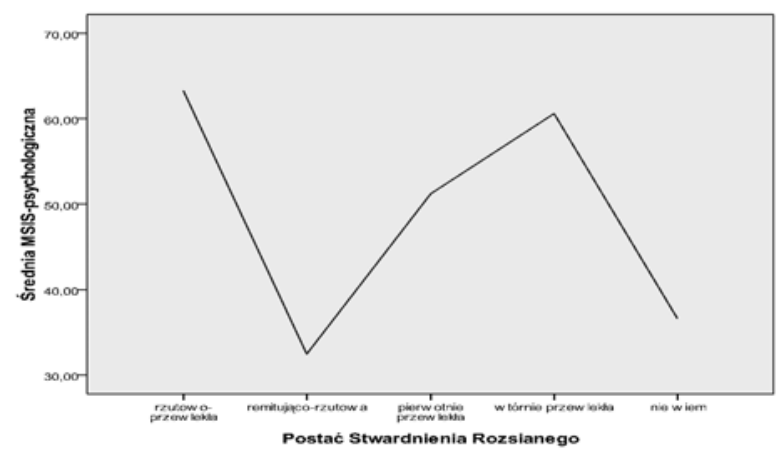

Wykres 3. Jakość życia badanych w sferze psychologicznej z uwzględnieniem postaci choroby wg MSIS-29

Wśród badanej grupy było zaledwie 3 ankietowanych, którzy byli osobami samotnymi po utracie współmałżonka. Mała liczność uniemożliwiła wykonanie formalnego testu. Analiza została ograniczona do oceny wzrokowej wykresu. Najwyższe wyniki, a tym samym najgorszą jakość życia, wskazywały osoby stanu wolnego - „panna/kawaler", oraz osoby będące w związkach małżeńskich. Wyniki kwestionariusza MSIS w obu sferach były podobne. Najlepszą jakość życia wskazywali wdowcy i wdowy, natomiast przy tak małej ilości osób nie można stwierdzić jednoznacznie, że jakość życia jest u nich najlepsza (Wykresy 4 i 5). W badanej grupie płeć (MSIS - fizyczna: $p=0,309$; MSIS - psychologiczna: $p=0,914$ ) oraz wykształcenie $(p=0,461)$ pacjentów nie wpływały istotnie na jakość życia. Natomiast prowadzona aktywność zawodowa badanych pacjentów istotnie determinowała sferę fizyczną i psychologiczną pacjentów $(p=0,000)$. Zdecydowanie najwyższe wyniki MSIS-29 zanotowano w grupie emerytów/rencistów (Wykresy 4 i 5). Najgorzej oceniali oni jakość życia w obu płaszczyznach funkcjonowania. Uwagę przykuwa niska ocena jakości życia i występowanie problemów natury psychologicznej zgłaszana przez osoby pozostające bez pracy - bezrobotni.

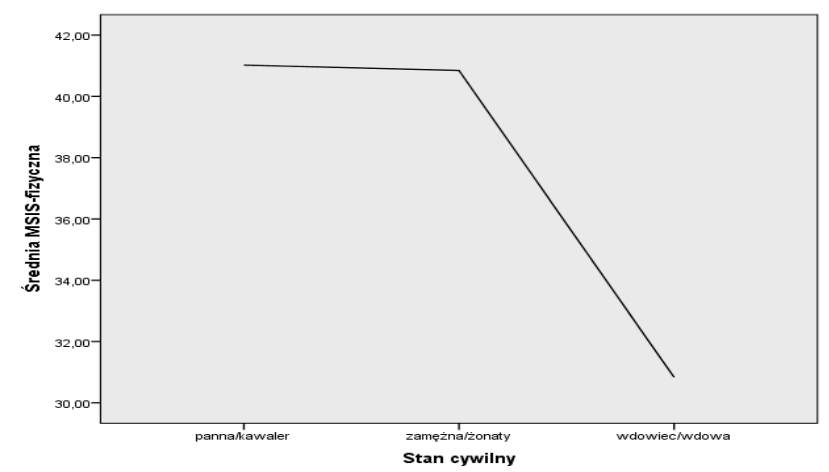

Wykres 4. Jakość życia badanych w sferze fizycznej z uwzględnieniem stanu cywilnego

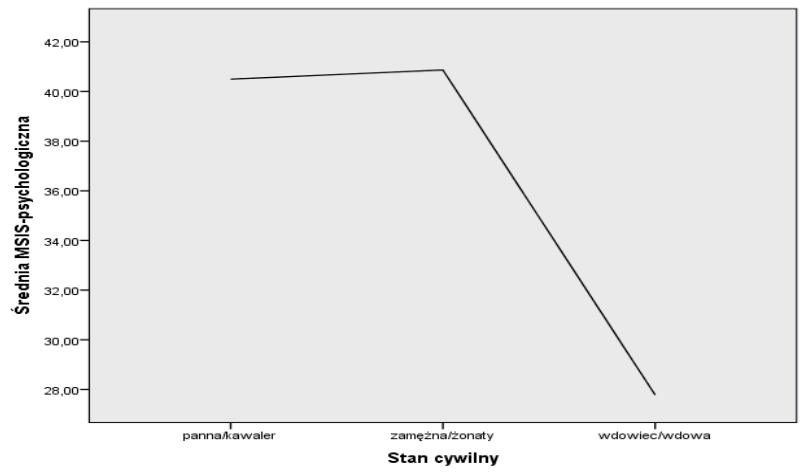

Wykres 5. Jakość życia badanych w sferze psychologicznej z uwzględnieniem stanu cywilnego

\section{Dyskusja}

Stwardnienie rozsiane jest rozpoznawane przede wszystkim w grupie osób młodych i stanowi coraz większy problem społeczny. Zapadalność na tę chorobę w krajach europejskich w ciągu roku szacuje się na około 4,3 przypadku na 100000 mieszkańców. Pierwsze objawy SM należące do "klinicznie izolowanego zespołu" (clinical isolated syndrome, (IS) nie stanowią podstawy do rozpoznania choroby, dlatego fakt ten ma dość istotny wpływ na wskaźnik epidemiologiczny. Dopiero kolejne wystąpienie rzutu bądź ujawnienie zmian progresywnych $w$ rezonansie magnetycznym stanowi podstawę do diagnozowania SM.

Choroba ta dwukrotnie częściej dotyka kobiet niż mężczyzn. Częstość występowania SM w populacji europejskiej wynosi około 80 przypadków na 100000 mieszkańców, w Polsce liczba ta wynosi 55. Dane dotyczące zachorowalności na SM na świecie są danymi wyłącznie orientacyjnymi [8]. Etiopatogeneza SM nie jest do końca zbadana, a przyczyny nieokreślone. Z dużym prawdopodobieństwem mechanizmy immunologiczne odgrywają pewną rolę w procesie rozwoju i postępu choroby, natomiast etiologia jest prawdopodobnie wieloczynnikowa [9] Obserwuje się także zwiększoną rolę dziedziczenia SM [10] Postać choroby zależy od indywidualnych cech jednostki. Z uwzględnieniem przebiegu choroby klasyfikuje się kliniczne postacie: remitująco-rzutowe (relapsing-remitting, RR), wtórnie postępującą (secondary progressive, SP) lub pierwotnie postępującą (primary progressive, PP) [11].

Wieloośrodkowe badanie pilotażowe przeprowadzone w Polsce wskazało, że najczęściej diagnozowaną postacią SM wśród pacjentów była postać RR (70,5\%), w dalszej kolejności wskazywano postać SP (16,8\%), PP (8,4\%) oraz postać "łagodną" stwardnienia rozsianego występującą u 2,5\% pacjentów [12]. W autorskich badaniach również potwierdziła się częstość występowania najbardziej rozpowszechnionej postaci SM - remitująco-rzutowej, którą zdiagnozowano u $38 \%$ badanych. 
Objawy pojawiające się w SM są następstwem uszkodzenia różnych części układu nerwowego, rozprzestrzenione w czasie i miejscu. Poza zaburzeniami czucia, występowaniem zespołów piramidowych, móżdżkowych, oczopląsu, zaburzeniami neurologicznymi, zmęczeniem czy zaburzeniami widzenia, pojawić się mogą odmienne stany emocjonalne - od depresyjnych po euforyczne, zaburzenia funkcji poznawczych, zaburzenia czynności seksualnych oraz zespoły bólowe [13].

Diagnoza stwardnienia rozsianego ma istotny wpływ na dalsze życie pacjenta i osób w jego najbliższym otoczeniu. Każdy z pacjentów odmiennie przyjmuje zmiany związane z postępującą chorobą. Wsparcie psychologiczne od najbliższych determinuje sposób radzenia sobie $w$ trudnych sytuacjach podczas trwania choroby. Postępująca niepełnosprawność i zaburzenie czynności funkcjonalnych wpływa negatywnie na sferę emocjonalną pacjenta, dlatego istotna staje się jakość życia w grupie osób ze stwierdzonym SM [14]. Termin jakości życia jest definiowany na wiele sposobów, ale najczęściej rozumiany jest jako ogólny stopień zadowolenia z życia i poczucie dobrostanu w sferze fizycznej, umysłowej, emocjonalnej oraz społecznej, posiadając przy tym charakter subiektywny [15].

Literatura podaje istotną zależność między jakością życia pacjentów z SM a wiekiem, przebiegiem choroby, sprawnością i prowadzonym leczeniem. Osoby starsze mniej sprawne ruchowo z postępującą chorobą gorzej oceniają jakość życia niż osoby młodsze [16]. Inni autorzy także potwierdzili pogarszającą się wraz z wiekiem jakość życia pacjentów [17], podobnie jak w badaniach autorskich, gdzie jakość życia pacjentów istotnie zależała od ich wieku. Ponadto badania wykazały, że jakość życia w grupie osób cierpiących na SM postaci remitująco-rzutowej była wyższa w porównaniu z grupą pacjentów ze zdiagnozowanym przewlekłym charakterem choroby. Doniesienia potwierdzające tę zależność można odnaleźć w wielu badaniach zawartych w literaturze [18]

W autorskich badaniach potwierdzono, iż dłuższy czas trwania choroby pogarsza jakość życia, co potwierdzają badania innych autorów [19]. Łabuz - Roszak wraz ze współpracownikami wskazali odmienną zależność i brak korelacji między jakością życia, a czasem trwania choroby, potwierdzili to także inni autorzy w swoich badaniach $[16,18]$. Ponadto wskazano brak wpływu aktywności zawodowej na jakość życia [16]. Nie potwierdziły tego faktu badania autorskie. W badanej grupie pacjentów emeryci i renciści najgorzej oceniali jakość życia w obu płaszczyznach. Niską ocenę jakości życia obserwowano także w grupie bezrobotnych.
Istotne stają się badania dotyczące jakości życia pacjentów z SM. Pierwszy raz badania takie zostały przeprowadzone w 1990 roku [20]. Od tego przełomowego momentu obecne badania prowadzone w celu oceny jakości życia służą nie tylko ewaluacji tego obszaru, ale także mają za zadanie wskazanie czynników, które w istotny sposób obniżają bądź poprawiają subiektywną ocenę jakości życia w grupie pacjentów.

\section{Wnioski}

- Jakość życia pacjentów ze stwardnieniem rozsianym jest niezadowalająca. Szczególnie ważne i częściej zgłaszane przez kobiety są problemy w sferze psychologicznej, będące następstwem choroby. Istotne staje się wsparcie psychologiczne w grupie osób chorujących na stwardnienie rozsiane. Mężczyźni gorzej oceniają sferę fizyczną.

- Przewlekła postać choroby istotnie obniża jakość życia u pacjentów.

- Poziom wykształcenia nie wpływa istotnie na jakość życia.

- Istotna dla wyższej jakości życia jest aktywność zawodowa. Osoby bezrobotne i pozostające na emeryturach bądź rentach niżej oceniają jakość życia w korelacji ze zdiagnozowanym stwardnieniem rozsianym.

- W grupie osób cierpiących na stwardnienie rozsiane zasadne staje się tworzenie grup wsparcia również wspólnych spotkań w celu zapobiegania wykluczeniu społecznemu tej grupy pacjentów.

\section{Oświadczenia}

Oświadczenie dotyczące konfliktu interesów

Autorzy deklarują brak konfliktu interesów.

\section{Źródła finansowania}

Autorzy deklarują brak źródeł finansowania.

Piśmiennictwo

1. Członkowska A, Członkowski A. Leczenie w neurologii, Wyd. PZWL, Warszawa 2005.

2. Kozubski W, Librski P. Neurologia. Wyd. PZWL, Warszawa 2006.

3. Prusiński A. Neurologia praktyczna. Wyd. PZWL, Warszawa 2005.

4. Bańka A, Derbis R. Psychologiczne i pedagogiczne wymiary jakości życia. Wyd. Gemini, Poznań - Częstochowa 1994.

5. Steuden S, Okła W. Jakość życia w chorobie. Wyd. KUL, Lublin 2007.

6. Trojanowska A. Znaczenie badań nad jakością życia w medycynie. Zdrowie Publiczne 2011, 1: 99-103.

7. Hobart JC, Riazi A, Lamping DL et all. Improving the evaluation of therapeutic interventions in multiple sclerosis: deve- 
lopement of a patient - based measure of outcome. Health Technology Assessment 2004, 8: 1-48.

8. Pugliatti M, Rosati G, Carton H. et all. The epidemiology of multiple sclerosis in Europe. Eur.J.Neurol. 2006, 13: 700-722.

9. Rejdak K. Ryzyko związane z nowymi sposobami leczenia SM. Pol Prz Neurol. 2010, 6A, 30

10. Grochans E, Wieder-Huszla S, Jurczak A. i wsp. Ocena wsparcia społecznego pacjentów ze stwardnieniem rozsianym. Probl Hig Epidemiol. 2008, 89(3): 419-422.

11. Lublin FD, Reingold SC. Defining uthe clinical course of multiple sclerosis: result of an international survey. National Multiple Sclerosis Society (USA) Advisory Committee on Clinical Trials of New Agents in Multiple Sclerosis. Neurology 1996, 46: 907-911.

12. Kułakowska A, Bartosik-Psujek H, Hozejowski R. i wsp. Selected aspects of the epidemiology of multiple sclerosis in Poland - a multicentre pilot study. Neurol.Neurochir.Pol. 2010, 44: 443-452.

13. Jamróz-Wiśniewska A, Papuć E, Bartosiuk-Psujek H. i wsp. Analiza walidacyjna wybranych aspektów psychomotorycznych polskiej wersji Skali Wpływu Stwardnienia Rozsianego na Jakość Życia Chorych (MSIS - 29). Neurol Neuroch Pol. 2007, 3:215-222.

14. Rotter I. Wpływ stanu funkcjonalnego, wspótistniejącej depresji oraz wybranych parametrów socjodemograficznych na jakość życia chorych po udarze niedokrwiennym mózgu. Ann Acad Med. Stetin. 2002, 48: 301-316.

15. Majkowicz M. Jakość życia w chorobie nowotworowej. WL de Walden-Galuszko K. (red) Psychoonkologia. Komitet Redakcyjno-Wydawniczy PTP; Biblioteka Psychiatrii Polskiej. Kraków 2000, 141-146.
16. Łabuz-Roszak B, Kubicka-Bączyk K, Pierzchała K. i wsp. Jakość życia chorych na stwardnienie rozsiane - związek z cechami klinicznymi choroby, zespołem zmęczenia i objawami depresyjnymi. Psychiatria Polska 2013, 3: 433-442.

17. Merkelbach S, Sittinger $H$, Koenig J. Is there a differentia impact of fatigue and physical disability an quality of luife in multiple sclerosis? J. Nerv. Ment. Dis. 2002, 190: 388-393.

18. Beiske AG, Naess H, Aarseth JH. et all. Health - related quality of life in secondary progressive multiple sclerosis. Mult.Scler. 2007, 13: 386-392.

19. Pfennings $L$, Cohen $L$, Herman A. wsp. Exploring differences between subgroups of multiple sclerosis patients in health related quality of life. J. Neurol. 1999, 246: 587-591.

20. Brownscombe I, Laupacis A, Rice GPA. Et all. Development of a disease - specific quality - of - life measure for multiple sclerosis. Neurol. 1990, 40(1): 142.

Zaakceptowano do edycji: 20.08.19 Zaakceptowano do publikacji: 26.09.19

\section{Adres do korespondencii:}

Hanna Skórzyńska

Wydział Nauk o Człowieku, Wyższa Szkoła Ekonomii I Innowacji

ul. Projektowa 4

20-209 Lublin

e-mail: hanna.skorzynska@gmail.com 